\title{
Bingöl İlinin Kırsal Turizm Potansiyelinin Belirlenmesi ve Bingöl İli Sakinlerinin Kırsal Turizm Algılamaları
}

\author{
Semiha KIZILOĞLU ${ }^{1}$, Ersin KARAKAYA ${ }^{2 *}$ \\ ${ }^{1}$ Atatürk Üniversitesi Ziraat Fakültesi Tarım Ekonomisi Bölümü, ERZURUM \\ ${ }^{2}$ Bingöl Üniversitesi Ziraat Fakültesi Tarım Ekonomisi Bölümü, BİNGÖL
}

\section{Öz}

Son zamanlarda TRB1 bölgesinin kalkınmasında kırsal turizm sektörü en önemli faktörlerden biri olmuştur. Bölgenin en önemi turizm potansiyelleri; tarih ve kültür, doğa, sağlık ve termal, inanç ve kış turizmi türleri olarak belirlenmiştir. Bingöl ilinin kırsal turizm potansiyelinin belirlenmesi amacı ile yapılmış olan bu çalışmada konu hakkındaki literatür taraması yapılmış ve aynı zamanda yöre halkının konu hakkında ki beklenti ve eğilimleri araştırılmış, olumlu ve olumsuz yönleri/etkileri analiz edilmiştir. Araştırmanın materyalini, Bingöl ili şehir merkezinde ikamet eden bireylerden yüz yüze görüşme tekniği kullanılarak toplanan yatay kesit verileri oluşturmuştur. Araştırma bulgularına göre; özellikle yeni yapısı ile gelişmeye açık olan kış turizmi, sağlık ve termal turizmi ve birçok turizm uygulamasını kapsayan yüzen adalar ilin önde gelen turizm potansiyelleri olarak belirlenmiştir. Bireylerin çoğunluğunun Bingöl'de turizmin gelişmesinin olumlu sonuçlar doğuracağına inandıkları belirlenmiştir. Bireylerin \%55.8'i yörenin gelişmesi için kaplıcalarla ilgili faaliyetlerin, \%53.5'i ise festivallerle ilgili faaliyetlerin geliştirilmesi gerektiğini ifade etmişlerdir. Sonuç olarak; Bingöl ilindeki bütün kurum ve kuruluşların bu konu üzerinde daha fazla durması, bu konuda uygulanabilir strateji ve politikalar belirlemeleri gerektiği sonucuna varılmıştır.

Anahtar Kelimeler: Bingöl, kırsal turizm, bölgesel kalkınma, TRB1 bölgesi

\section{Determination of Rural Tourism Potential of Bingol Province and Rural Tourism Perceptions of The Inhabitants of Bingol City}

\begin{abstract}
Recently, the rural tourism sector has been one of the most important factors in the development of the TRB1 region. The most important tourism potentials of the region are determined; history and culture, nature, health and thermal, belief and winter tourism types. This study is concerned with rural tourism potential of Bingol. Literature survey was conducted on the subject, opinions and dispositions of the local population were investigated, favourable and unfavourable sides/effects were analysed. The material of the study will be horizontal cross-sectional data collected from face-to-face interview techniques from individuals residing in the city center of Bingöl province. According to research findings; As the leading tourism potential of the province are defined that especially with its new structure cover winter tourism, health and thermal tourism and many floating islands tourism applications which are open to development. It has been determined that the majority of the individuals believe that the development of tourism in Bingöl will have positive results. 55.8\% of the individuals stated that activities related to spas should be developed and $53.5 \%$ of activities related to festivals should be developed for the development of the region. As a result; All the institutions and organizations in Bingöl province need more attention on this issue and it is necessary to determine the applicable strategies and policies in this regard.
\end{abstract}

Keywords: Bingol, rural tourism, regional development, TRB1 region 


\section{Giriş}

Kırsal turizm; ekonomik sıkıntılardan dolayı göçün yaşandığ 1 ve nüfusun az olduğu kırsal kesimlerde yörenin ekonomik kalkınmasına katkı sağlamayı ve göçü engellemeyi hedefleyen bir turizm faaliyetidir. Kırsal turizmde, asıl hareket noktası, doğal yaşam ve tarımsal değerlere duyulan ilgiyle başlar, daha sonra kırsal alana yönelik olarak yapılan aktiviteler yöresel özelliklerden faydalanarak geliştirilebilir (Mansuroğlu ve Dağ, 2016). Kırsal alanlarda gerçekleştirilen kırsal turizm, çok yönlü ve karmaşık bir faaliyettir. Kırsal turizm: çiftlik turizmi, yeşil turizm veya yayla turizmi olarak bilinmekle beraber, doğa tatillerini ve özellikle de eko turizm, alışveriş, kayak, bisikletli ve atlı doğa gezileri, macera, rafting, spor, termal turizm, avcılık ve balıkçılık, sanat, tarih ve etnik yapıya bağlı bir turizm şeklidir (Soykan 2006, Çeken ve ark., 2007). Kırsal turizmi oluşturan bileşenleri bilmek, kırsal turizmin kavram olarak daha iyi anlaşılması için oldukça önemlidir (Şekil 1).

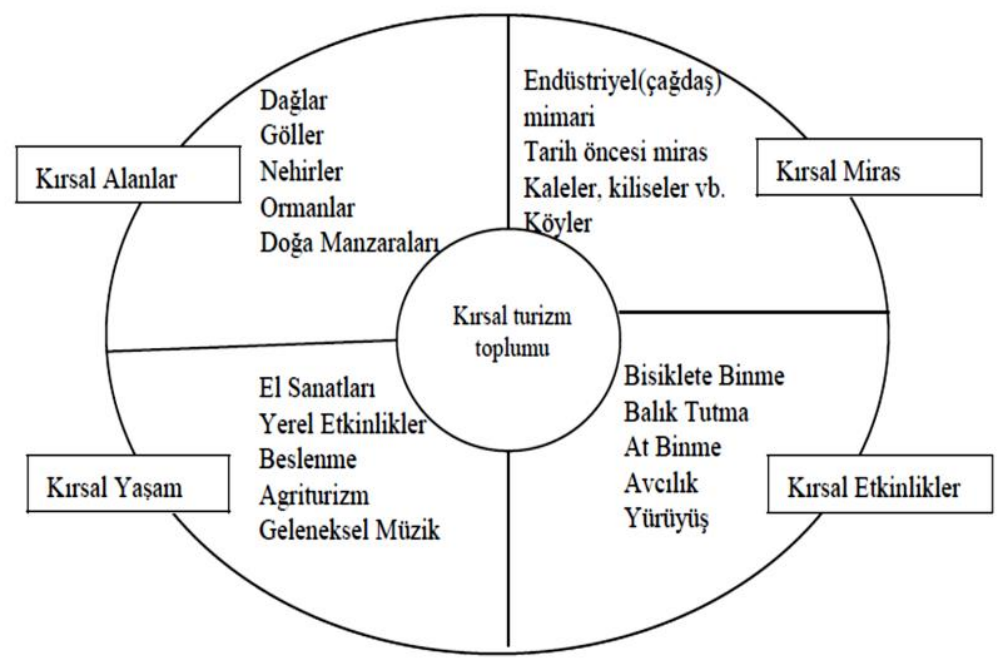

Şekil 1. Kırsal Turizm Kavramı (Kırsal Turizm Bileşenleri)

Kırsal turizm aktivitelerinin çoğunlukla doğa turizmi içerisinde gerçekleştiği belirlenmiş, eko turizm ve çiftlik turizminin bir bölümünün, tarım turizminin ise tamamının kırsal turizmle ilişkilendirildiği saptanmıştır (Ayaz, 2012, Ongun ve ark., 2015). Hem kırsal kesimlerde yapılan faaliyetler, hem de şehir içinde veya yakınlarında kırsallığı çağrıştıran faaliyetler kırsal turizm faaliyeti olarak sayılabilir (Şekil 2).

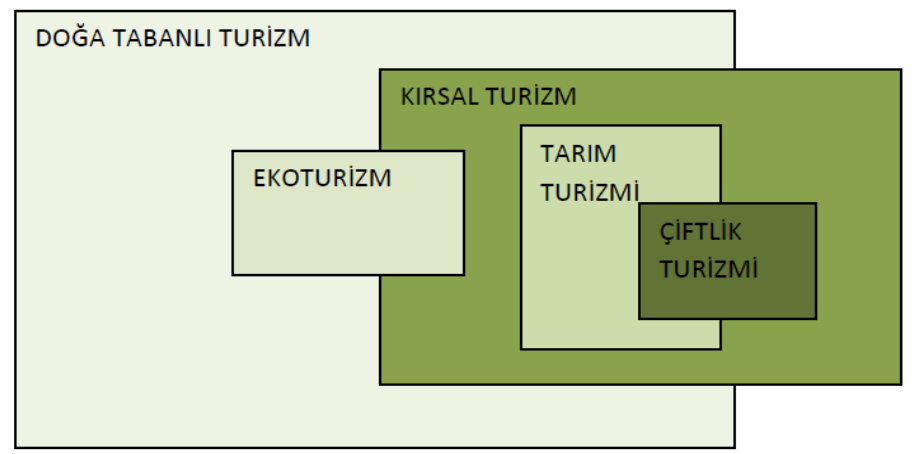

Şekil 2. Kırsal turizm ve diğer turizm türleri arasındaki ilişki

Türkiye kırsal turizm sektöründe en hızlı büyüyen pazarlardan biri olmakla beraber, aynı zamanda orta ve uzun sürede en yüksek büyüme potansiyeline sahip ülkelerden biri konumuna gelmiştir. Son zamanlarda TRB1 bölgesinin kalkınmasında kırsal turizm sektörü, en önemli faktörlerden biri olmuştur. Bölgenin en önemli turizm potansiyelleri; tarih ve kültür, doğa, sağlık ve termal, inanç ve kış turizmi türleri olarak belirlenmiştir (Anonim, 2012).

Bingöl ilinin kırsal turizm potansiyelinin belirlenmesi amacı ile yapılmış olan bu çalışmada, konu hakkında literatür taraması yapılmış ve aynı zamanda yöre halkının konu hakkında ki beklenti ve eğilimleri araştırılmış, olumlu ve olumsuz yönleri/etkileri analiz edilmiştir. 


\section{Materyal ve Metot}

\subsection{Materyal}

Bu araştırmanın birincil verilerini Bingöl kent merkezindeki 271 adet bireyden 2018 y1lında elde edilen anket verileri oluşturmaktadır. İkincil veriler ise konu ile ilgili kamu kurumlarından, ulusal ve uluslararası bilimsel araştırmalardan, dergi ve çeşitli çalışmalardan derlenmiştir.

\subsection{Metot}

Örnek hacmini (anket yapılan tüketici sayısı) belirlemek için aşağıdaki formül kullanılmıştır (Baş, 2008; Gözener ve Sayıl1, 2013).

$$
n=\frac{N \times t^{2} \times p \times q}{d^{2} \times(N-1)+t^{2} \times p \times q}
$$

Formülde;

n: Örneğe alınacak birey sayısı,

N: Hedef kitledeki birey sayısı (157 921),

p: İncelenen olayın gerçekleşme olasılığı (0.50),

q: İncelenen olayın gerçekleşmeme olasılığ 1 (0.50),

t: Standart normal dağılım değeri (1.65),

d : Örnekleme hatası (0.05)'dır.

Formülde $\% 90$ güven aralığ $1, \% 5$ hata payı ve maksimum örnek hacmine ulaşabilmek için $\mathrm{p}=\mathrm{q}=0.5$ olarak alınmış ve örnek hacmi 271 olarak hesaplanmıştır.

Bingöl ili kent merkezinde yaşayan bireylerin Bingöl ili kırsal turizm merkezlerine yönelik ifadelere katılım durumunun belirlenmesinde "Kabul düzeyi beş ölçekli likert” ölçeği kullanılmıştır. Likert türü ölçekleme tekniği, uygulamalı sosyal bilim araştırmalarında çok yoğun olarak kullanılan ölçekleme tekniği olup, ölçekleme tekniğinin kurulması ve uygulanması noktasındaki titizlik, araştırmanın sonuçlarının doğruluğu bakımından son derece önemlidir (Bayat, 2014).

\section{Bulgular ve Tartışma}

\subsection{Bingöl'ün Türkiye ve Bölgesindeki Yeri ve Kırsal Kesim Ekonomisi}

Bingöl ili; Doğu Anadolu Bölgesi'nin Yukarı Fırat bölümünde $3827^{\prime}$ ve $40^{\circ} 27^{\prime}$ doğu boylamlarıyla $41^{\circ} 20^{\prime}$ ve 3954' kuzey enlemleri arasında yer almaktadır. Bingöl ilinin komşuları; doğuda Muş kuzeyde Erzincan ve Erzurum batıda Tunceli ve Elazığ güneyde ise Diyarbakır'dır. Bingöl il merkezinde bulunan DSİ Parkı doğal güzellikleri yansıtan mesire yeri özelliği taşır, ilaveten Yado Çeşmesi, Özkale Vali Abdülkadir SARI dinlenme ve spor tesisleri ve Çır şelalesi doğa harikaları olarak ön plana çıkan yerlerdir (Anonim, 2013; Mansuroğlu ve Dağ, 2016). Adaklı İlçesindeki akarsu boylarındaki ağaçlıklar ve yaylalar, düzenlenmiş bir gezinti yeri olmadığı için ilçe halkı tarafından gezinti yerleri olarak değerlendirilmektedir. Ayrıca peri suyu gelecekte rafting turizminin yapılacağı yerlerden biri olarak ön plana çıkmaktadır (Anonim, 2013). Genç ilçesinde bulunan çok sayıdaki akarsu kenarları ve yaylalar da gezinme alanı olarak değerlendirilmektedir. Kığ İlçe sınırlarında yer alan Şeytan Dağları Yaban Hayatı Geliştirme Sahası doğa harikası olması yanında Av Turizmi bakımından değerli bir kırsal turizm potansiyelidir. Solhan İlçesinde bulunan Yüzen Adalar Tabiat Anıtı ilçenin eşsiz turizm potansiyeli olarak öne çıkmaktadır (Anonim, 2013).

\subsection{Bingöl İlinde Yapılabilecek Doğa Turizm Uygulamaları}

Yayla Turizmi, Foto Safari, Mağara Turizmi, Yaban Hayatı Gözlemciliği, Doğa Yürüyüşü (Trekking), Av Turizm, Botanik (flora) Turizmi, Termal Turizm, Kış Turizmi ve Akarsu Turizmi Bingöl için uygun doğa turizm çeşitleridir. Bağış (2017a) ve Bağış (2017b) tarafından yapılan çalışmalarda Bingöl ilinin sahip olduğu doğal potansiyelleri ile önemli bir altyapıya sahip olduğu belirlenmiştir. Karlıva ilçesi sınırları içinde yer alan Kübik Mağarasında Paleolitik ve Neolitik ve Tunç Çağına ait izlere rastlanmıştır (Anonim, 2012). (Şekil 3) Mansuroğlu ve Dağ (2016) Kübik Mağarası'nın duvarlarının çeşitli figürler ile oyularak süslenmiş olduğunu bildirmiştir. Yolçatı kayak merkezi ve yeni yapılan Hesarek kayak merkezi turizm çeşitliliği bakımından kış 
sporları ile beraber sporcuların her türlü aktiviteleri için potansiyel alanlardır (Şekil 4). Yapılan diğer bir çalışmada da Yolçatı kayak merkezi ve Hesarek kayak merkezinin yerel halk tarafından turizm amaçlı olarak ilk sırada tercih edildiği bildirilmiştir (Mansuroğlu ve Dağ, 2016).

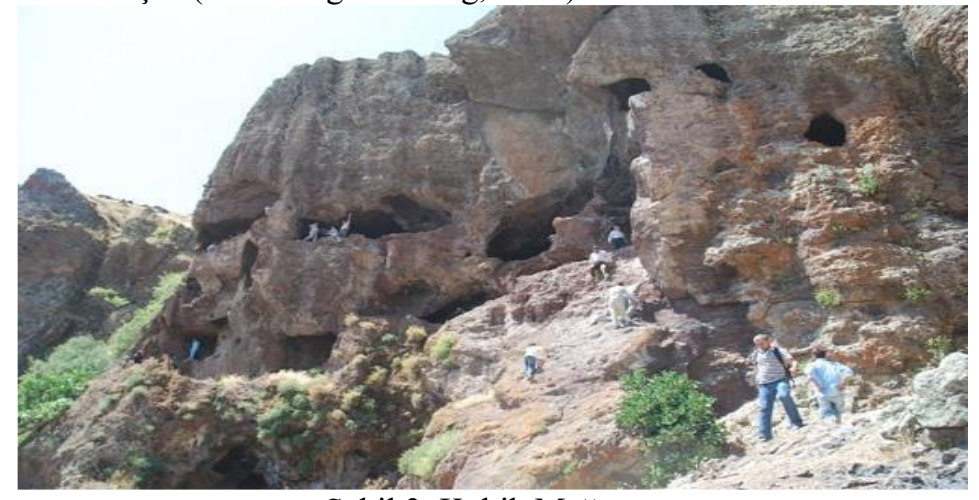

Şekil 3. Kübik Mağarası
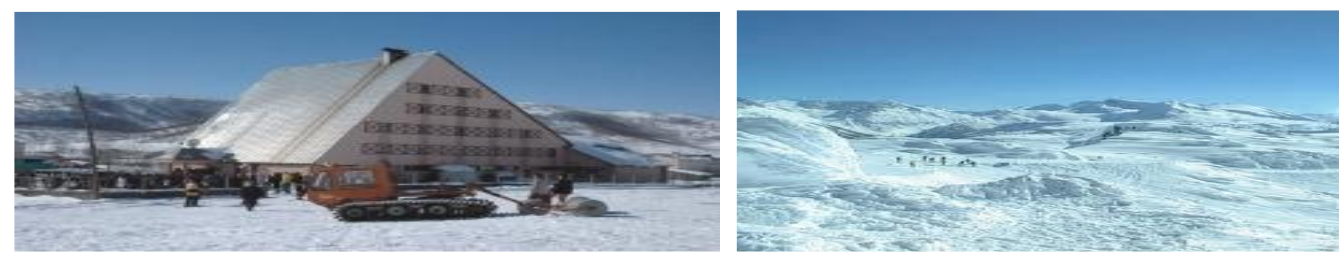

Şekil 4. Yolçatı ve Hesarek kayak merkezleri

Bingöl'de bulunan Murat Nehri, Peri Suyu ve Göynük çayı ile Özlüce Baraj Gölü su sporları aktiviteleri için potansiyel alanlardır. Kiğı ve Yedisudan geçen Kelhaç Deresi de özellikle rafting olanağı açısından değerlendirilebilir (Şekil 5) (Doğa Koruma ve Milli Parklar Genel Müdürlüğü, 2013; Kiğı Kaymakamlığı, 2014; Mansuroğlu ve Dağ, 2016).

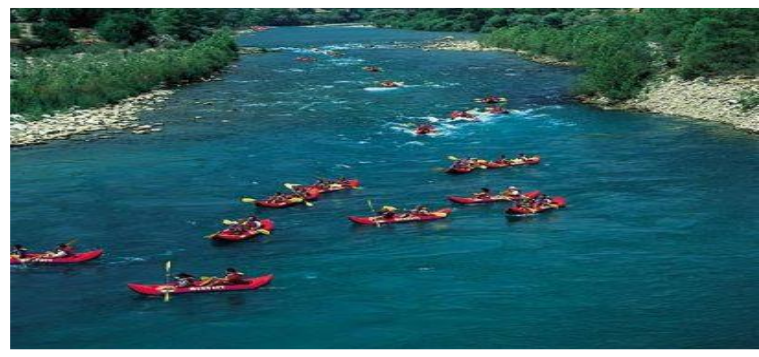

Şekil 5. Peri suyu

Bingöl merkez ilçeye bağlı 1lıcalar beldesinde bulunan kaplıcalara ulaşım rahatlıkla sağlanabilmektedir. Yapılan araştırmalar sonucunda, kaplıca suyunun içildiğinde, mide motolitesini artırdığı, maden suyu olarak içilebileceği, romatizma ve kadın hastalıklarına iyi geldiği belirlenmiştir (Şekil 6). Yapılan bir çalışmada, çeşitli hastalıklara şifa olan kaplıcaların, çevre illerden önemli ölçüde rağbet gördüğü bildirilmiştir (Kement ve Batga, 2016).

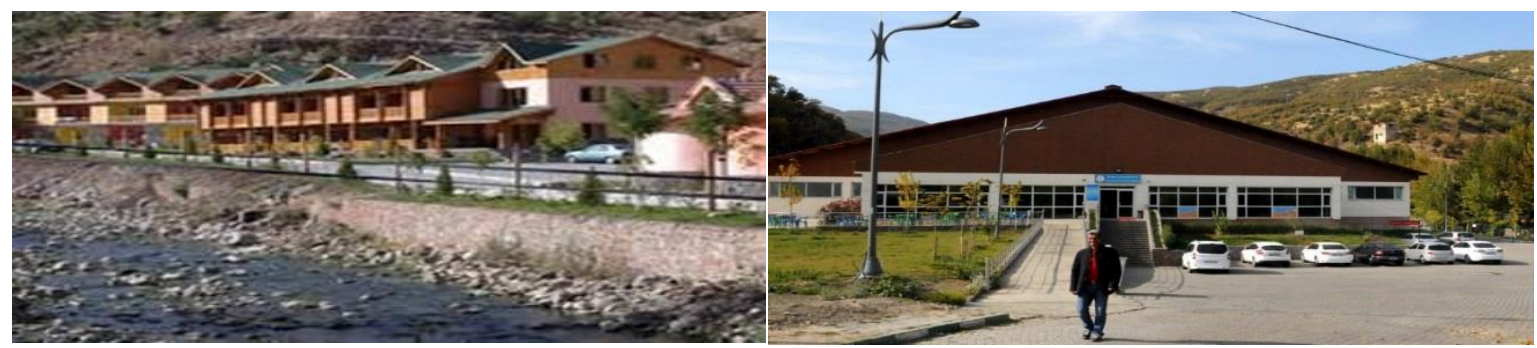

Şekil 6. Ilıcalar termal tesisleri

Solhan ilçesinde bulunan Solhan Yüzen Adalar Tabiat Anıtı ilin tek koruma statüsü olan ve doğa turizmi amaçlı kullanılan potansiyel turizm alanıdır (Şekil 7). Mansuroğlu ve Dağ (2016) tarafından yapılan çalışmada Çevre ve Şehircilik Bakanlığının (2013) yılında yapmış olduğu 2040 yılı öngörülerine göre Solhan ilçesindeki Yüzen 
Adaların doğa turizmine öncülük edebileceği bildirilmiştir.

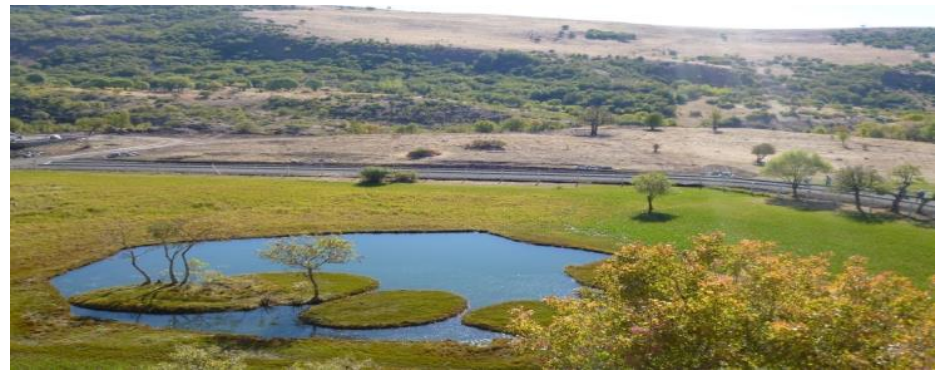

Şekil 7. Yüzen ada

\subsection{Kent Merkezinde Yaşayan Bireylerin Kırsal Turizm Algılamaları}

\subsubsection{Bireylerin Sosyoekonomik ve Demografik Özellikleri}

Anket yapılan bireylerin \%79.1'inin bayan, \%20.9'unun ise erkek olduğu, \%44.2'sinin evli, \%55.8'inin bekâr olduğu belirlenmiştir. Bireylerin yaşlarının 17 ile 52 arasında değiştiği ve yaşlarının ortalamasının 27 olduğu tespit edilmiştir. Okuryazar olan bireylerin oranı \%2.3, ilkokul mezunu olan bireylerin oranı \%19.3, ortaokul mezunu olan bireylerin oranı $\% 17$, lise mezunu olan bireylerin oranı \%28.6 ve üniversite mezunu olan bireylerin oranı ise \%32.8 olarak bulunmuştur. Bireylerin meslek gruplarının dağılımına bakıldığında \%39.5'inin memur, \%23.4'ünün ev hanımı, \%20.4'ünün öğrenci, \%11.9'unun serbest meslek ve \%4.8'inin ise esnaf olduğu sonucu belirlenmiştir. Bireylerin Bingöl kent merkezinde oturma sürelerinin 1-43 yıl arasında değiştiği ve ortalama 15 yıl olduğu tespit edilmiştir.

\subsection{Bireylerin Bingöl İli Kırsal Turizm Potansiyeli İle İlgili Düşünceleri}

Bireylerin \%7'si Bingöl ilinin altyapı açısından turizm sektörü için yeterli donanıma sahip olduğunu düşünürken \%93'ü ise bu konuda olumsuz düşündüklerini belirtmişlerdir. Bireylerin \%53.5’i Bingöl halkının bölgeye gelen turistlere yeterli önemi gösterdiğini, $\% 46.5$ 'i ise yeterli önemi göstermediğini ifade etmişlerdir (Şekil 8).

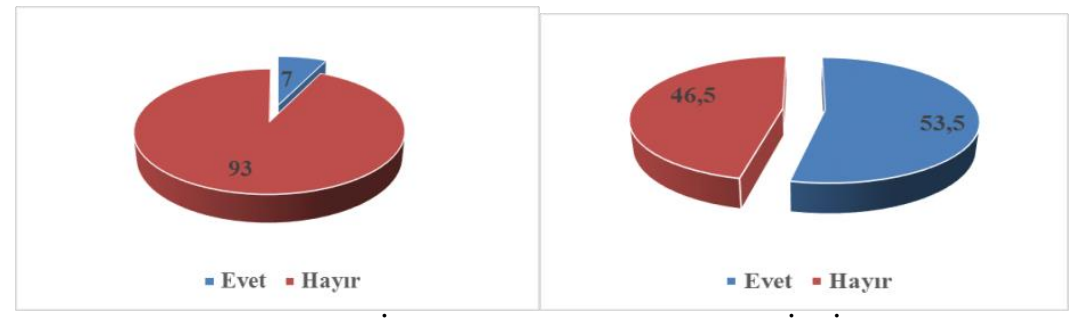

Şekil 8. Bireylerin Bingöl İli Kırsal Turizm Potansiyeli İle İlgili Düşünceleri

Bireylerin \%39.5'i turistlerin Bingöl'e kayak merkezi için geldiğini ve bu kapsamda kayak merkezinin Bingöl ilinin çekicilik unsuru olduğunu, \%30.2'si turistlerin Bingöl'e kaplıcalar için geldiğini ve bu kapsamda kaplıcaların Bingöl ilinin çekicilik unsuru olduğunu, \%23.3'ü turistlerin Bingöl’e yüzen ada için geldiğini ve bu kapsamda yüzen adanın Bingöl ilinin çekicilik unsuru olduğunu ve \%9.3’ü ise diğer nedenleri belirtmişlerdir (Şekil 9). Orhan ve Doğanay (2017) tarafından yapılan çalışmada, Şavşat ilçesindeki turizm potansiyelinin en önemli ayağını, Karagöl-Sahara Milli Parkının oluşturduğu tespit edilmiştir.

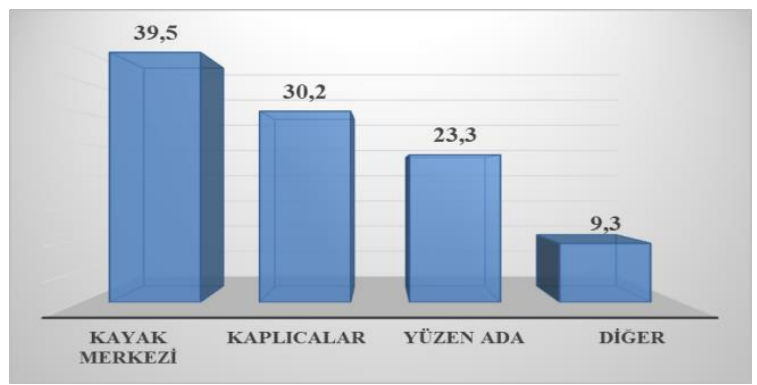

Şekil 9. Turistlerin Bingöl'e gelme nedeni ve bu kapsamda Bingöl’ün çekicilik unsuru (\%) 
Bireylerin çoğunluğu Bingöl'de turizmin gelişmesinin olumlu sonuçlar doğuracağına inandıkları belirlenmiş, \%46.5'i yeni iş ve kazanç kaynağı doğacağını, \%41.9'u halkın sosyo ekonomik seviyesinin gelişeceğini ifade etmişlerdir. Bireylerin \%9.3'ü Bingöl'de turizmin gelişmesiyle ev fiyatlarının artacağını ve halkın alım gücünün azalacağını, \%2.3’ü ise gençlerin ahlakının bozulacağını ifade ettikleri belirlenmiştir (Şekil 10). Erzurum Oltu ilçesinde Denk ve Mil (2016) tarafindan yapılan çalışmada, genel olarak Oltu ilçesinde yaşayan yerel halkın kırsal turizm hakkında algılarının olumlu yönde olduğu sonucu tespit edilmiştir.

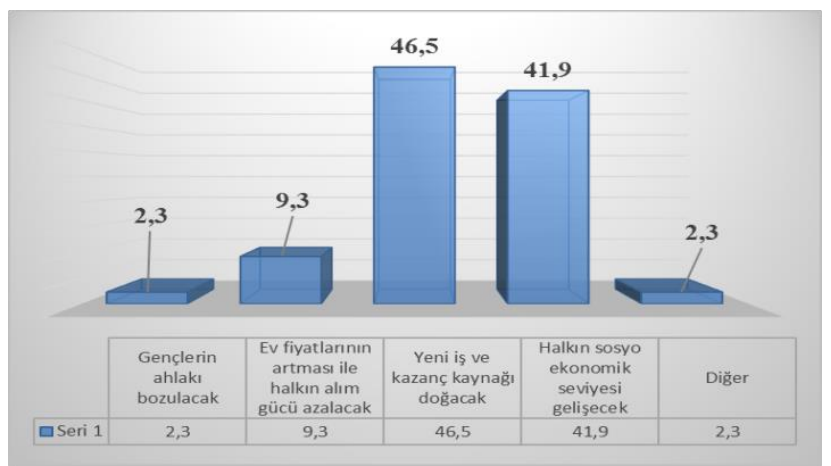

Şekil 10. Bireylere göre Bingöl'de turizmin gelişmesinin doğuracağı sonuçlar (\%)

Bireylerin \%69.8'i Bingöl'deki konaklama tesislerinin sayı ve donanım olarak yetersiz olduğunu, \%30.2'si ise yeterli olduğunu düşündüklerini ifade etmişlerdir (Şekil 11).

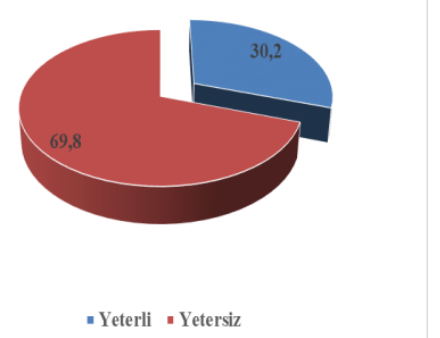

Şekil 11. Bingöl'deki konaklama tesislerinin sayı ve donanım olarak yeterlilik durumu (\%)

Kırsal turizm için bölgedeki en uygun yerin belirlenmesinde kırsal turizmin uygulanabilirliği açısından doğal bozulmamış yapı, tarımsal ve hayvansal faaliyetlerin ve bölge halkının davranışları gibi unsurların dikkate alınması son derece önemlidir. Bu açıdan bireylerin \%39.5’i Merkez ilçeyi, \%23.3'ü Solhan ve Karlıova ilçelerini kırsal turizm için uygun yerler olarak gördüklerini ifade etmişlerdir (Şekil 12).

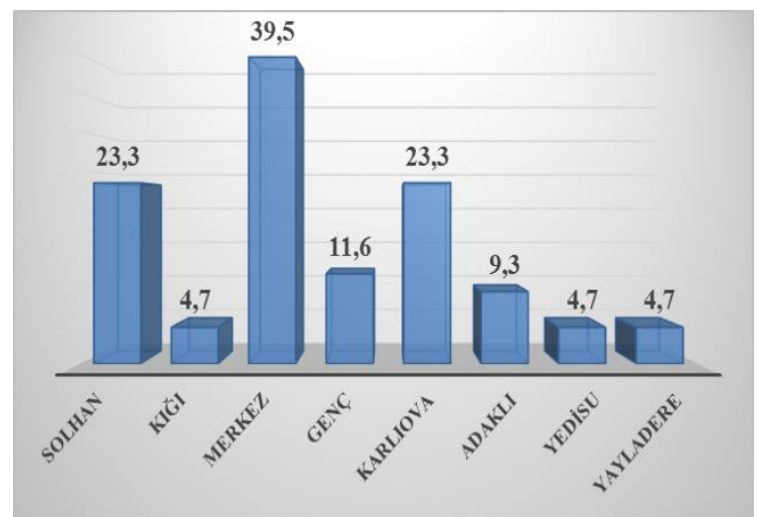

Şekil 12. Bireylere göre Bingöl için en uygun kırsal turizm yeri (\%)

Bireylerin genel olarak Bingöl ili turizm merkezleri ile ilgili düşünceleri tablo 1'de verilmiştir. Bireyler genel olarak turizm merkezlerindeki sosyal donatıların ve fiyatların uygunluğunu çok kötü, yeme içme olanaklarını ise iyi olarak değerlendirmişlerdir. Karakaş (2012) Diyarbakır ili eğil ilçesinin kırsal turizm potansiyelini belirlemek amacıyla yaptığı çalışmada yeterli barınma ve dinlenme tesislerinin olmadığı sonucunu belirlemiştir. Yozgat ilinde Ersoy ve ark. (2018) tarafından yapılan çalışmada da mevcut tesislerin sayısının yetersiz olduğu sonucu bulunmuştur. Yapılan başka bir çalışmada, Kilis ilinde var olan konaklama tesislerinin yetersiz olduğu, 
halkın da geçim kaynağını sağlayabilecek olan köy pansiyonculuğunun geliştirilmesi gerektiği sonucuna ulaşılmıştır (Harbalığlu ve ark., 2013). Dağdeviren ve ark. (2017) yaptıkları çalışmada, Ilgaz ilçesinde tesis sayısının yeterli düzeyde olmadığını tespit etmişlerdir.

Tablo 1. Bireylerin Bingöl ili turizm merkezleri ile ilgili düşünceleri

\begin{tabular}{|c|c|c|c|c|c|c|}
\hline \multirow[t]{2}{*}{ İfadeler/katılım durumu } & \multicolumn{6}{|c|}{ Oranlar $(\%)^{*}$} \\
\hline & 1 & 2 & 3 & 4 & 5 & Ort \\
\hline Konaklama olanakları & 16.7 & 26.2 & 47.6 & 9.5 & - & 2.50 \\
\hline Yeme içme olanakları & 14.3 & 9.5 & 38.1 & 38.1 & - & 3.00 \\
\hline Ulaşım & 42.9 & 11.9 & 31 & 14.3 & - & 2.17 \\
\hline İletişim & 24.4 & 19.5 & 34.1 & 19.5 & 2.4 & 2.56 \\
\hline Ürün ve hizmet kalitesi & 19 & 23.8 & 38.1 & 16.7 & 2.4 & 2.60 \\
\hline Fiyatların uygunluğu & 40.5 & 31 & 19 & 9.5 & - & 1.98 \\
\hline $\begin{array}{l}\text { Sosyal donatılar (mescit, eğlence } \\
\text { merkezi vb.) }\end{array}$ & 66.7 & 19 & 9.5 & 2.4 & 2.4 & 1.55 \\
\hline $\begin{array}{l}\text { Acil durum hizmetleri (arama } \\
\text { kurtarma, sağlık vb.) }\end{array}$ & 16.7 & 14.3 & 45.2 & 19 & 4.8 & 2.81 \\
\hline
\end{tabular}

Bireylerin \%55.8'i yörenin gelişmesi için kaplıcalarla ilgili faaliyetlerin, \%53.5'i ise festivallerle ilgili faaliyetlerin geliştirilmesi gerektiğini ifade etmişlerdir (Şekil 13). Mesci ve Öztürk (2017) yapmış oldukları çalışma sonucunda Ulusal ve Uluslararası festivallerin artırılması gerektiğini belirlemişlerdir.

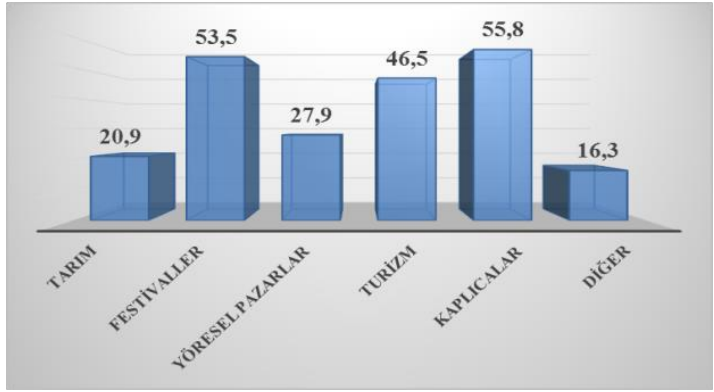

Şekil 13. Yörenin gelişmesi için bireylere göre geliştirilmesi gereken faaliyetler (\%)

Bireylere göre Bingöl'de turizm faaliyetlerinin geliştirilmesinin yöreye olumlu etki yapıp yapmama durumuna ait sonuçların dağılımı şekil 14'de verilmiştir. Sonuçlara bakıldığında Bingöl'de turizm faaliyetlerinin geliştirilmesinin yöreye olumsuz katkı yapacağını düşünen birey olmadığı, çok az sayıdaki (\%2.3) bireylerin bilmiyorum seçeneğini işaretledikleri ve genel olarak bireylerin \%97.7'sinin bu konuda olumlu düşündüğü sonucu ortaya çıkmıştır.

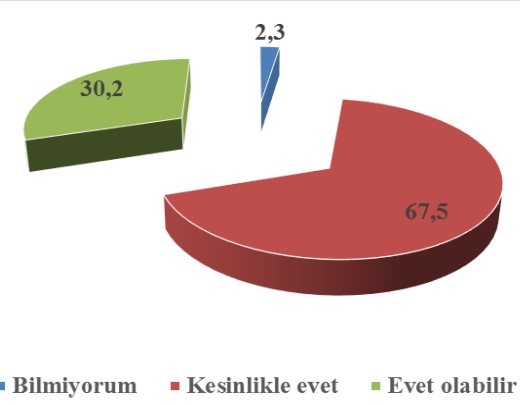

Şekil 14. Bingöl'de turizm faaliyetlerinin geliştirilmesinin yöreye olumlu etki yapma durumu \%

Bireylerin \%46.5'i Bingöl ili ve ilçelerinde turizmin geliştirilmesinde yöresel kültürü tanıtma ve sağlık ve termal turizm alanlarının daha uygun olacağını ifade ettiği, doğal hayatı tanıma amaçlı geziler alanının daha uygun olduğunu düşünen bireylerin oranı \%37.2 ve festivallere yönelik etkinliklerin daha uygun olduğunu 
düşünen bireylerin oranı ise \%34.9 olarak belirlenmiştir (Şekil 15). Bireylerin tamamının Bingöl'de turizmin geliştirilebileceğine inancının tam olduğu bu konuda ise derneklerin sivil toplum kuruluşlarının ve belediyenin faaliyetlerini arttırması gerektiğini ifade ettikleri belirlenmiştir. Ersoy ve ark (2018) tarafından yapılan çalışmaya göre, Yozgat ili kırsal turizminin güçlü yönleri; Yozgat ilinde bulunan termal tesisler, kültürel, tarihi ve doğal güzellikler olarak belirlenmiştir. Ongun ve ark. (2015) burdur ilinin kırsal turizm potansiyelinin belirlenmesi üzerine yaptıkları çalışmada, yöresel festival ve etkinliklere ağırlık verilmesi gerektiği sonucunu belirlemişlerdir. Türkiye turizm stratejisi kapsamında kırsal turizmin değerlendirildiği bir çalışma sonucunda, yerel halk ile STK'ların ortak etkinlikler, gezi turları, vb. organizasyonlar düzenleyerek ortak hareket etmesi gerektiği sonucu belirlenmiştir (Dursun ve ark., 2017). Ercan ve ark. (2017)'da yaptıkları çalışmada, Ortaca'nın kırsal turizm potansiyelinin değerlendirilmesi için yerel yönetimlerin ve halkın, ortak bilinç ile hareket etmesi gerektiğini belirlemişlerdir.

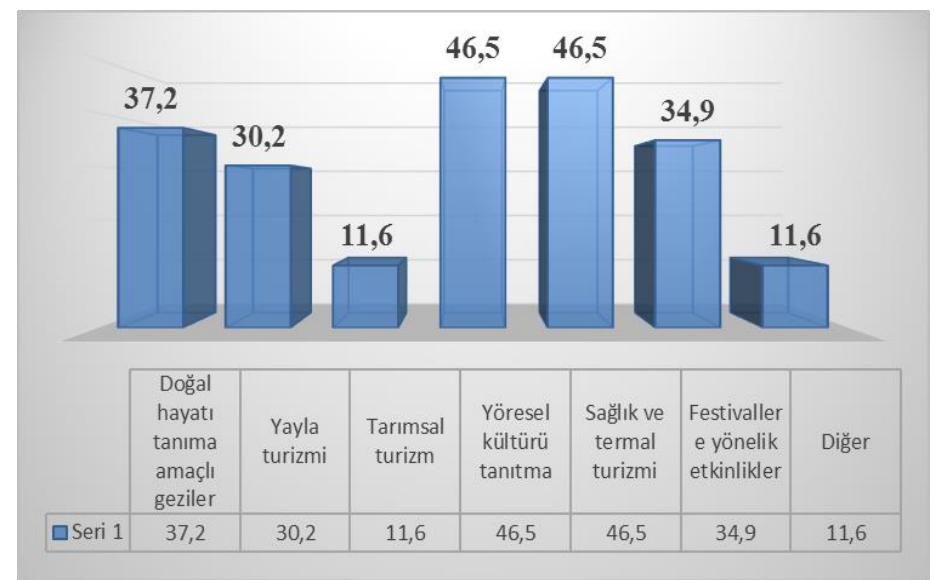

Şekil 15. Bingöl ilinde turizmin geliştirilmesinde bireylere göre öncelikli alanlar (\%)

\section{Sonuç ve Öneriler}

Bingöl ilinin Türkiye'de turizm aktivitelerinin çeşitlendirilmesine katkı sağlayacak potansiyeli olduğu, yerel halkın, turizm faaliyetlerinden gelir sağlaması ve görüşlerinin yapılacak çalışmalarda dikkate alınmasının özellikle kırsal turizmin sürdürülebilirliği bakımından son derece önemli olduğu kanısına varılmıştır. Özellikle yeni yapısı ile gelişmeye açık olan kış turizmi, sağlık ve termal turizmi ve birçok turizm uygulamasını kapsayan yüzen adalar ilin önde gelen turizm potansiyelleri olarak ortaya çıkmaktadır. Bingöl ilinin hemen hemen her ilçesinde geliştirilmeye ve uygulanmaya açık bir kırsal turizm faaliyetinin olduğu sonucuna varılabilir. Bingöl'de turizm sektörünün gelişiminde, yaylalar, dağlar, şifalı su kaynakları, nehirler koruma statüsü özelliği olan yüzen ada ve güneşin doğuşunun izlendiği kala tepesi, en önemli doğal unsur değerler olarak sayılabilir (Anonim, 2013). Bingöl ilinde özellikle yayla turizmi, rafting ve balıkçılık, doğa yürüyüşü ve botanik geziler, kış turizmi ve termal turizm uygun olan ilçelerde desteklenmelidir.

Kent merkezinde yaşayan bireylerin kırsal turizm algılamaları ile ilgili genel sonuçlara bakacak olursak; bireylerin \%7'si Bingöl ilinin altyapı açısından turizm sektörü için yeterli donanıma sahip olduğunu ve bireylerin \%53.5'i Bingöl halkının bölgeye gelen turistlere yeterli önemi gösterdiğini, ifade etmişlerdir. Bireylerin genel olarak turistlerin Bingöl'e kayak merkezi, kaplıcalar ve yüzen ada için geldiklerini ve bu üç turizm değerinin Bingöl ili için turizm açısından çekicilik unsuru olduklarını belirtmişlerdir. Bireylerin çoğunluğu Bingöl'de turizmin gelişmesinin olumlu sonuçlar doğuracağına inandıkları belirlenmiştir. Bingöl'deki konaklama tesisleri sayı ve donanım olarak Bingöl ili kent merkezindeki bireylere göre yetersiz olarak belirlenmiştir. Kırsal turizmin uygulanabilirliği açısından bireyler Bingöl ilinde Karlıova, Merkez ve Solhan ilçelerinin uygun yerler olduğunu ifade etmişlerdir. Bireyler genel olarak turizm merkezlerindeki sosyal donatıların ve fiyatların uygunluğunu çok kötü, yeme içme olanaklarını ise iyi olarak değerlendirmişlerdir. Bireylerin \%55.8'i yörenin gelişmesi için kaplıcalarla ilgili faaliyetlerin, \%53.5'i ise festivallerle ilgili faaliyetlerin geliştirilmesi gerektiğini ifade etmişlerdir. Bingöl'de turizm faaliyetlerinin geliştirilmesinin yöreye olumsuz katkı yapacağını düşünen birey olmadığı, çok az sayıdaki (\%2.3) bireylerin bilmiyorum seçeneğini işaretledikleri ve genel olarak bireylerin \%97.7'sinin bu konuda olumlu düşündüğü sonucu ortaya çıkmıştır. Bireylerin \%46.5'i Bingöl ili ve ilçelerinde turizmin geliştirilmesinde yöresel kültürü tanıtma ve sağlık ve termal turizm alanlarının daha uygun olacağını ifade ettiği, doğal hayatı tanıma amaçlı geziler alanının daha uygun olduğunu düşünen bireylerin oranı $\% 37.2$ ve festivallere yönelik etkinliklerin daha uygun olduğunu düşünen bireylerin oranı ise \%34.9 olarak belirlenmiştir. Bireylerin tamamının Bingöl'de turizmin 
geliştirilebileceğine inancının tam olduğu bu konuda ise derneklerin sivil toplum kuruluşlarının ve belediyenin faaliyetlerini arttırması gerektiğini ifade ettikleri belirlenmiştir. Bingöl il sakinlerinin kırsal turizm algılarının kontrol edilmesi amacıyla ilgili turizm sektörlerinde memnuniyet anketleri düzenlenerek sektörün avantaj veya dezavantajlı olduğu durumlar belirlenip gerekli önlemler alınabilir. İlgili turizm sektörlerinde halkla ilişkiler biriminin devreye sokulması sorunların tespit edilmesi ve çözülmesi açısından önemli olabilir. İldeki konaklama tesislerinin sayısal ve donanımsal olarak yeterli duruma getirilmesi ayrıca ulusal kurumlarla yapılacak destekleyici anlaşmalarla tesislerdeki fiyatların uygun olması yerel halkın ilin kırsal turizm algısını olumlu yönde etkileyecektir.

Sonuç olarak; kültürel, tarihi, doğal bakımdan zengin olan Bingöl ilindeki bütün kurum ve kuruluşların bu konu üzerinde daha fazla durması, bu konuda uygulanabilir strateji ve politikalar belirlemelidir. Bingöl'de yapılacak turizm odaklı etkinlik sayısının artması yörenin tanıtımı ve pazarlanması için faydalı olabilir. Bu nedenle yöresel festival ve etkinliklere ağırlık verilmelidir. Kırsal alandaki yerel halkın ve turizm faaliyetleri yürüten işletmelerin kırsal turizm konusunda düzenlenecek eğitimlerle bilinçlendirilmesi ilde kırsal turizmin gelişmesine ivme kazandırabilir. Ulusal ve uluslararası basında bölgenin tanıtımının yapılması, konuyla ilgili web sitesinin oluşturulması, yöresel ürünler ve el sanatlarının tanıtımı için aktivitelerin düzenlenmesi, konuyla ilgili broşür ve afiş gibi destek yayınların artması bölgedeki turizmin gelişimini hızlandırabilir.

\section{Teşekkür}

Bu çalışma kapsamında değerli vakitlerini ayırıp görüşlerini bizlerle paylaşan Bingöl il merkezindeki tüm katılımcılara ve Bingöl Üniversitesi Ziraat Fakültesi Tarla Bitkileri Bölümü Yüksek lisans öğrencisi Büşra ÇAĞLAYAN'a anketin uygulanması ve verilerin bilgisayar ortamına girilmesindeki yardımları için teşekkür ederim.

\section{Kaynaklar}

1. Anonim (2012). Fırat Kalkınma Ajansı (http://www.fka.org.tr )Erişim 23 Haziran 2018).

2. Anonim (2013). Bingöl İlinde Doğa Turizmi Master Planı 2013 - 2023. T.C Orman Ve Su İşleri Bakanlığ1 Doğa Koruma Ve Milli Parklar Genel Müdürlüğü 13. Bölge Müdürlüğü Bingöl Şube Müdürlüğ̈̈. 2013

3. Ayaz N (2012). Kırsal Turizm ve Paydaşları: Belediye Başkanlarının Tutumlarına Yönelik Bir Araştırma. Yayınlanmamış Doktora Tezi, Gazi Üniversitesi Bilimleri Enstitüsü Turizm İşletmeciliği Eğitimi Ana Bilim Dal1, Ankara.

4. Bağıș B (2017a). İktisadiyat Perspektifi Üzerine: Sermaye Üretimi, Katma Değer Yaratma ve Bölgesel Kalkınma, İktisadiyat, 1(1), pp. 13-38.

5. Bağış B (2017b). İl Ekonomisinin Dönüşüm Zamanı. Retrieved from http://bingolgazetesi.com.tr/haberilekonomisinin-donusum-zamani-89396.html (2017, Şubat 3).

6. Baş T (2008). Anket. Araştırma Yöntemleri Dizisi:2, Seçkin Yayıncılık, 5. Baskı, Ankara.

7. Bayat B 2014. Uygulamalı sosyal bilim araştırmalarında ölçme, ölçekler ve "likert" ölçek kurma tekniği. Gazi Üniversitesi İktisadi ve İdari Bilimler Fakültesi Dergisi 16:3 1-24.

8. Çeken H, Karadă̆ L, Dalgın T (2007). Kırsal kalkınmada yeni bir yaklaşım kırsal turizm ve Türkiye'ye yönelik teorik bir çalışma. Artvin Çoruh Üniversitesi Orman Fakültesi Dergisi, 8:1 1-14.

9. Çevre ve Şehircilik Bakanlığı (2013) Malatya-Elazığ-Bingöl-Tunceli 1/100.000 Ölçekli Çevre Düzeni Planı Açıklama Raporu.

10. Dağdeviren A, Özdemir H, Göker G (2017). Ilgaz ilçesinin turizm potansiyeli. Journal of Tourism and Gastronomy Studies 5:4 504-533.

11. Denk E, Mıl B (2016). Erzurum Oltu ilçesinin kırsal turizm potansiyeli ve yerel halkın turizm algılamaları. Uluslararası Sosyal ve Ekonomik Bilimler Dergisi, 6:2 7-15.

12. Doğa Koruma ve Milli Parklar Genel Müdürlüğü (2013). Bingöl İlinde Doğa Koruma Master Planı 2013-2023

13. Dursun C, Demiral M, Zengin B, Batman O (2017). 2023 türkiye turizm stratejisi kapsamında kırsal turizmin değerlendirilmesi. Uluslararası Kırsal Turizm ve Kalkınma Dergisi, 1:1: 1-5.

14. Ercan F, Dalgın T, Atak O (2017). Muğla/ortaca ilçesinin kırsal turizm potansiyelini değerlendirmeye yönelik bir swot analizi. Uluslararası Sosyal Araştırmalar Dergisi, 10:52 1416-1424.

15. Ersoy Y, Tehci A, Ersoy B (2018). Kırsal turizm potansiyelinin swot analizi ile değerlendirilmesi: Yozgat ili örneği, Hitit Üniversitesi Sosyal Bilimler Enstitüsü Dergisi, 11:1 649-664.

16. Gözener B, Sayılı M (2013). Tüketicilerin Açık Süt ve Süt Ürünleri Tüketim Tercihlerinin İncelenmesi Tokat-Turhal İlçesi Örneği. Sosyal Bilimler Araştırmaları Dergisi. I, (2013): 160-175. 
17. Harbalığlu M, Özel G, Erkan B (2013). Kilis ilinin kırsal turizm potansiyeli ve sosyo-ekonomik kalkınma açısından değerlendirilmesi. Uluslararası Sosyal ve Ekonomik Bilimler Dergisi, 3:2 55-61.

18. Karakaş A (2012). Eğil ilçesi kırsal turizm potansiyelinin değerlendirilmesi. KMÜ Sosyal ve Ekonomik Araştırmalar Dergisi 14:23 5-18.

19. Kement Ü, Batga B (2016). Bingöl'de Termal Amaçlı Hizmet Veren İşletmelerin Rekreatif ve Turistik Açıdan Değerlendirilmesi. Journal of Tourism and Gastronomy Studies 4/4 57-74.

20. Kiğı Kaymakamı̆̆̆ 2014 (http://www.kigi.gov.tr) (Erişim Tarihi: 14.02.2019).

21. Mansuroğlu S, Dağ V (2016). Bingöl ilinin peyzaj potansiyelinin kırsal turizm olanakları (swot analizi yöntemi kullanılarak) açısından değerlendirilmesi. Mediterranean Agricultural Sciences, 29:1 9-16.

22. Mesci M, Öztürk E (2017). Akçakoca'nın kırsal turizm eğilimleri ve geleceğe yönelik öneriler. Aksaray Üniversitesi İktisadi ve İdari Bilimler Fakültesi Dergisi, 9:3 73-82.

23. Ongun U, Gövdere B, Kaygısız, Durgun A (2015). Burdur ilinin kırsal turizm potansiyelinin değerlendirilmesi: sorunları ve çözüm önerileri. Mehmet Akif Ersoy Üniversitesi Sosyal Bilimler Enstitüsü Dergisi 7:12 99-116.

24. Ongun U, Gövdere B, Çiçek U (2016). Yeşil ova'nın kırsal turizm potansiyelinin swot analizi ile değerlendirilmesi. Süleyman Demirel Üniversitesi Vizyoner Dergisi, 7:16 75-88.

25. Orhan F, Doğanay H (2017). Türkiye'nin sakin şehirlerinden biri olan şavşat'in turizm potansiyelinin belirlenmesi ve değerlendirilmesi. Iğdır Üniversitesi Sosyal Bilimler Dergisi / Igd Univ Jour Soc Sci. 12 303-326.

26. Soykan F (2006). Avrupa'da Kırsal Turizme Bakış Kazanılan Deneyim. II. Balıkesir Ulusal Turizm Kongresi, 20-22 Nisan 2006; Balıkesir, s: 71-87. 